\title{
Genetic Parameters for Tunisian Holsteins Using a Test-Day Random Regression Model
}

\author{
H. Hammami, ${ }^{*} \dagger$ B. Rekik,‡ H. Soyeurt, ${ }^{\star} \S$ A. Ben Gara, $\ddagger$ and N. Gengler*\# ${ }^{1}$ \\ *Animal Science Unit, Gembloux Agricultural University, B-5030 Gembloux, Belgium \\ †Livestock and Pasture Office, 1002 Tunis Belvedere, Tunisia \\ ¥Ecole Supérieure d’Agriculture de Mateur, 7030 Mateur, Tunisia \\ $\S$ Fonds pour la Formation à la Recherche dans l'Industrie et l'Agriculture, B-1000 Brussels, Belgium \\ \#National Fund for Scientific Research, B-1000 Brussels, Belgium
}

\begin{abstract}
Genetic parameters of milk, fat, and protein yields were estimated in the first 3 lactations for registered Tunisian Holsteins. Data included 140,187; 97,404; and 62,221 test-day production records collected on 22,538; 15,257; and 9,722 first-, second-, and third-parity cows, respectively. Records were of cows calving from 1992 to 2004 in 96 herds. (Co)variance components were estimated by Bayesian methods and a 3-trait-3-lactation random regression model. Gibbs sampling was used to obtain posterior distributions. The model included herd $\times$ test date, age $\times$ season of calving $\times$ stage of lactation [classes of 25 days in milk (DIM)], production sector $\times$ stage of lactation (classes of 5 DIM) as fixed effects, and random regression coefficients for additive genetic, permanent environmental, and herd-year of calving effects, which were defined as modified constant, linear, and quadratic Legendre coefficients. Heritability estimates for 305-d milk, fat and protein yields were moderate $(0.12$ to 0.18$)$ and in the same range of parameters estimated in management systems with low to medium production levels. Heritabilities of test-day milk and protein yields for selected DIM were higher in the middle than at the beginning or the end of lactation. Inversely, heritabilities of fat yield were high at the peripheries of lactation. Genetic correlations among 305$\mathrm{d}$ yield traits ranged from 0.50 to 0.86 . The largest genetic correlation was observed between the first and second lactation, potentially due to the limited expression of genetic potential of superior cows in later lactations. Results suggested a lack of adaptation under the local management and climatic conditions. Results should be useful to implement a BLUP evaluation for the Tunisian cow population; however, results also indi-
\end{abstract}

Received May 24, 2007.

Accepted January 30, 2008.

${ }^{1}$ Corresponding author: gengler.n@fsagx.ac.be cated that further research focused on data quality might be needed.

Key words: genetic parameter, random regression model, test-day yield, dairy cattle

\section{INTRODUCTION}

The use of test-day (TD) models to analyze milk production data has several advantages over the use of lactation models. Test-day models account for environmental factors that could affect the performance of cows throughout the lactation (Ptak and Schaeffer, 1993; VanRaden, 1997). Also, no extension of incomplete lactations is needed, and TD models are better suited to predict daily production, to detect outliers, and, consequently, to help decision making for management purposes (Mayeres et al., 2004). Test-day models use larger data sets, however, and usually require estimates of more parameters than a lactation model. However, they facilitate the use of information from ongoing operations, the inclusion of data from different recording schemes by weighing every TD accordingly, and the use of data with missing milk components at given TD if used in a multivariate analysis.

Genetic parameters of TD milk traits using random regression (RR) models have been reported for several cow populations from fitting various functions to model additive genetic lactation curves (Jamrozik and Schaeffer, 1997; Strabel and Misztal, 1999; Jakobsen et al., 2002; Druet et al., 2003; Strabel et al., 2005; Muir et al., 2007). Legendre orthogonal polynomials seem to efficiently describe the evolution of milk yields during a complete lactation of dairy cows in different management conditions (Rekaya et al., 1999; Gengler et al., 1999; Brotherstone et al., 2000). Recently, RR models applied to TD records have been implemented by most Interbull members for the evaluation of dairy populations.

The size of the Holstein cow population has substantially increased over the recent years in Tunisia through the import of pregnant heifers and semen from 
temperate countries. Most cows are daughters of sires with strong genetic links to the United States and Canadian and some European populations (Hammami et al., 2007). In 2000, Holsteins accounted for more than $40 \%$ of the 455,000 total cows in Tunisia. Cows enrolled in the A4 official milk recording system (since the 1960s) were about $10 \%$ of the total Holstein population in 2000 (Rekik et al., 2003). Alternate and owner farm recording systems are being encouraged to increase the number of Holstein cows enrolled in the national milk recording system. Unfortunately, the data generated by the milk recording is currently not sufficiently and adequately used, especially because of the lack of a genetic evaluation. Replacements and culling operate only on an intraherd index for milk yield. Milk components are rarely considered in making breeding decisions. Selection of candidate animals should, however, be made on EBV to improve milk production under local conditions. Prediction of BLUP breeding values requires estimates of variance components. The implementation of a TD model for the genetic evaluation of milk traits using a $R R$ model, as done by most Interbull countries, requires genetic parameters under Tunisian conditions. Tunisia has been a member of the International Committee for Animal Recording and Interbull since 1980; however, full participation of Tunisia in these organizations requires a genetic evaluation system.

The objective of this study was, therefore, to estimate (co)variance components of milk, fat, and protein yields in the first 3 lactations with a RR model by using Bayesian methods and Gibbs sampling. This study was a first step toward a Tunisian genetic evaluation system for yield traits based on a TD model.

\section{MATERIALS AND METHODS}

\section{Data}

Data were provided by the Tunisian Genetic Improvement Center, Livestock and Pasture Office, Tunis. Original data from the official milk recording database included 1,321,782 TD records collected on cows calving from 1992 to 2004 . The number of herds enrolled in the milk recording plan has been increasing since the 1990s. For this reason, not all cows were in their first lactation when they were first enrolled in a recording system. Furthermore, the numbers of TD records for milk, fat, and protein yields were not equal, because fat and protein yields were missing in some TD due to technical reasons. In this study, only records from the first 3 lactations were retained. All third-lactation cows were required to have first- and second-lactation records. Likewise, second-lactation cows had first-lactation records. A minimum of 5 TD records, for milk, fat, and protein yields, were required for a cow observation to be included in the analysis, which excluded cows with very short lactations. Records obtained before 5 or after 330 DIM were also discarded. The TD records up to 330 DIM were kept to improve modeling lactation curves around 305 DIM. Herds with fewer than 4 cows per herd $\times$ year of calving were omitted. Further edits excluded irregular data for daily milk yield $(<1.0$ and $>70 \mathrm{~kg})$, fat content $(<1.5 \%$ and $>9 \%)$, and protein percentage $(<1 \%$ and $>7 \%)$. Edited data included 140,187; 97,404; and 62,221 TD records collected on 22,538; 15,257; and 9,722 first-, second-, and third-lactation cows that were daughters of 1,$720 ; 1,461$; and 1,219 sires, respectively. Lactations had to start between 22 and $45 \mathrm{mo}, 32$ and $65 \mathrm{mo}$, and 42 and $80 \mathrm{mo}$ of age for the first-, second-, and third-lactation cows, respectively.

Four seasons (fall, winter, spring, and summer) and 6 subclasses for age at calving for the first lactation ( $<26 \mathrm{mo}, 26$ to 27,28 to 29,30 to 31,32 to 33 , and $>33$ mo), 4 classes for the second lactation $(<40 \mathrm{mo}, 40$ to 42,43 to 45 , and $>45 \mathrm{mo}$ ), and 3 classes for the third lactation $(<54 \mathrm{mo}, 54$ to 58 , and $>58 \mathrm{mo})$ were defined. Four production sectors (state, cooperative, commercial, and private farms) were defined, because large management differences exist among these types of farms. A full description of the data used is given in Table 1.

\section{Analysis}

Data were analyzed with a 3-trait-3-lactation RR TD model. The matrix notation of the model is

$$
\mathbf{y}=\mathbf{X b}+\mathbf{Q}(\mathbf{Z a}+\mathbf{Z} \mathbf{p}+\mathbf{W h})+\mathbf{e}
$$

where $\mathbf{y}=$ a vector of milk, fat, and protein yields; $\mathbf{b}=$ a vector of the fixed effects: herd $\times$ test date, age $\times$ season of calving $\times$ classes of 25 DIM, and sector of production $\times$ classes of 5 DIM (nested within parities); $\mathbf{p}=$ a vector of $R R$ coefficients for permanent environmental (PE) effect; $\mathbf{a}=$ a vector of $R R$ coefficients for animal genetic (AG) effect; $\mathbf{h}=$ a vector of $R R$ coefficients for herd-year of calving common environmental effect $(\mathbf{H Y}) ; \mathbf{e}=$ a vector of residual effects; $\mathbf{Q}=$ a matrix of 3 modified Legendre polynomials (constant, linear, quadratic) as defined by Gengler et al. (1999); and X, $\mathbf{Z}$, and $\mathbf{W}=$ incidence matrices relating observations to various effects. The covariance structure of the model is

$$
\mathrm{V}\left[\begin{array}{c}
\mathbf{a} \\
\mathbf{p} \\
\mathbf{h} \\
\mathbf{e}
\end{array}\right]=\left[\begin{array}{cccc}
\mathbf{A} \otimes \mathbf{K}_{\mathbf{a}} & \mathbf{0} & \mathbf{0} & \mathbf{0} \\
\mathbf{0} & \mathbf{I} \otimes \mathbf{K}_{\mathbf{p}} & \mathbf{0} & \mathbf{0} \\
\mathbf{0} & \mathbf{0} & \mathbf{I} \otimes \mathbf{K}_{\mathbf{h}} & \mathbf{0} \\
\mathbf{0} & \mathbf{0} & \mathbf{0} & \mathbf{R}
\end{array}\right]
$$

Journal of Dairy Science Vol. 91 No. 5, 2008 
Table 1. Description of test-day data with standard deviation in parentheses

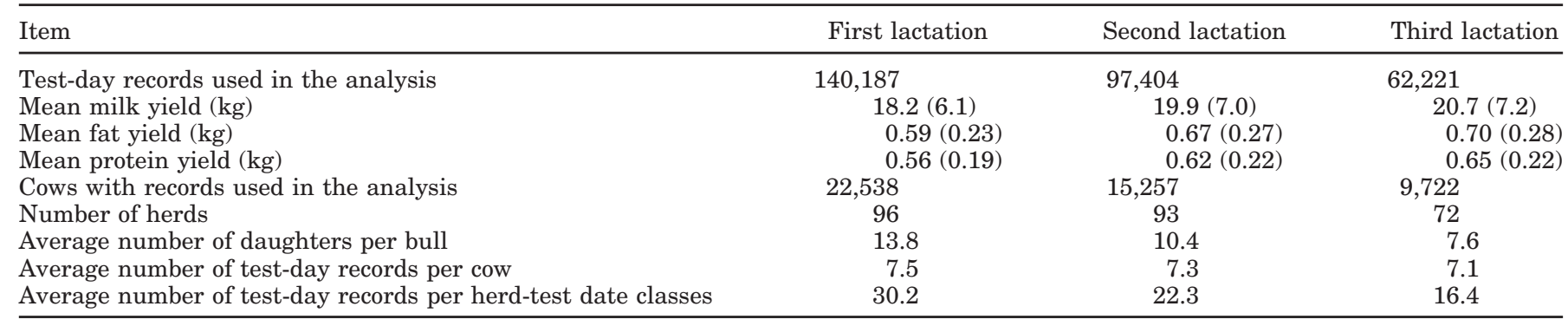

where $\mathbf{K}_{\mathbf{a}}=$ the $27 \times 27$ covariance matrix of the AG regression coefficients; $\mathbf{A}=$ the $\mathrm{AG}$ covariance matrix among all animals; $\mathbf{K}_{\mathbf{p}}=$ the $27 \times 27$ covariance matrix of the $\mathrm{PE}$ regression coefficients; $\mathbf{K}_{\mathbf{h}}=$ the $27 \times 27$ covariance matrix of the $\mathrm{HY}$ regression coefficients, and $\mathbf{R}=$ a $9 \times 9$ diagonal matrix of residual variances.

Variance components were estimated with a Bayesian approach via the Gibbs sampling algorithm as implemented by Misztal et al. (2002). Posterior means of variance components, heritability, and correlation estimates were obtained using 100,000 samples after a burn-in of 20,000 samples. Convergence of Gibbs chains was monitored by inspection of plots related to selected parameters.

The genetic variance matrix among all DIM and traits was obtained following Druet et al. (2003), as $\mathbf{G}=$ $\mathbf{Q K}_{\mathrm{a}} \mathbf{Q}^{\prime}$ where $\mathbf{G}=$ a $9 \times 330$ by $9 \times 330$ genetic (co)variance matrix for all 9 traits and DIM ranging from 1 to $330 \mathrm{~d}$ and $\mathbf{Q}=$ a $9 \times 330$ by 27 matrix with the values of the 9 coefficients of the third-order Legendre polynomial for each DIM from 1 to $330 \mathrm{~d}$ for every trait. The $\mathrm{PE}$ and $\mathrm{HY}$ effect (co)variance matrices were similarly defined, and $\mathbf{P}$ and $\mathbf{H}$ matrices were estimated from the $\mathbf{K}_{\mathbf{p}}$ and $\mathbf{K}_{\mathbf{h}}$ matrices.

Genetic (co)variances for 305-d yields were obtained by using $\mathbf{G}_{\text {lact }}=\mathbf{S G}_{305} \mathbf{S}^{\prime}$ where $\mathbf{G}_{\text {lact }}=$ the $\mathbf{9} \times \mathbf{9}$ (co)variance matrices among 305-d lactation yields for the 9 traits; $\mathbf{G}_{305}=$ a partial matrix derived from $\mathbf{G}$ with dimensions $9 \times 305$ by $9 \times 305$; and $\mathbf{S}=$ a 9 by $9 \times 305$ summation matrix that sums the contributions of a given TD to the 305-d yield for each trait. The same approach was used to derive $\mathbf{P}_{\text {lact }}$ and $\mathbf{H}_{\text {lact }}$ matrices. Heritabilities for 305-d yields were computed as the ratio of the genetic variances to the sum of the genetic, permanent environmental, herd-year, and residual variances. Correlations between traits $i$ and $j$ were computed as the ratio of the covariance $\operatorname{cov}(i, j)$ to the square root of the products of the variances of trait $i$ and $j$.

Residuals were calculated for each DIM as the difference between $\mathbf{y}$ and $\hat{\mathbf{y}}$ where $\hat{\mathbf{y}}=$ the predicted value obtained by fitting the model. Average residuals can be used to determine the accuracy of the model (Jamrozik and Schaeffer, 1997). Mean values of these residuals over all TD records were estimated and plotted.

\section{RESULTS AND DISCUSSION}

\section{Lactation Curves}

Figure 1 shows the trend of the mean residuals over DIM for milk yield in the first lactation. The residuals were scattered about the horizontal axis. These results indicate a satisfactory description of the lactation curve and an adequate representation of the data by the proposed model. A similar trend of mean residuals over DIM was observed across the lactation trajectory for the second parity. However, the fluctuation around zero was slightly higher in the third lactation, which can be explained by fewer TD records in later lactations. When applying an alternative model (results not shown) with a parametric curve in the fixed part (third-order Legendre polynomials for season-age of calving), and without the random HY effect, undesirably large fluctuations of mean residuals across the lactation were observed (i.e., a large under- or overestimation of milk yield in the different lactation phases was obtained). Druet et al. (2003) also found that the use of fixed classes assured the best fit compared with parametric curves (Legendre polynomials, Ali-Schaeffer curve, and Wilmink curve). Due to their large number of parameters, fixed classes allow more flexibility than do parametric curves. In addition, any record in the parametric curve will influence the whole curve. In contrast, the influence of the data is local in the case of fixed classes. Also, classes of DIM can be cross-classified with other effects with the potential to influence lactation shapes, such as production sectors in our case.

\section{Variance Components}

Estimates of AG, PE, HY, and R variances of the first RR coefficient (intercept) for milk, fat, and protein yields are given in Table 2 . All variances increased with parity for all yield traits. Similar trends were reported in previous studies on other data (Rekaya et al., 1999; 


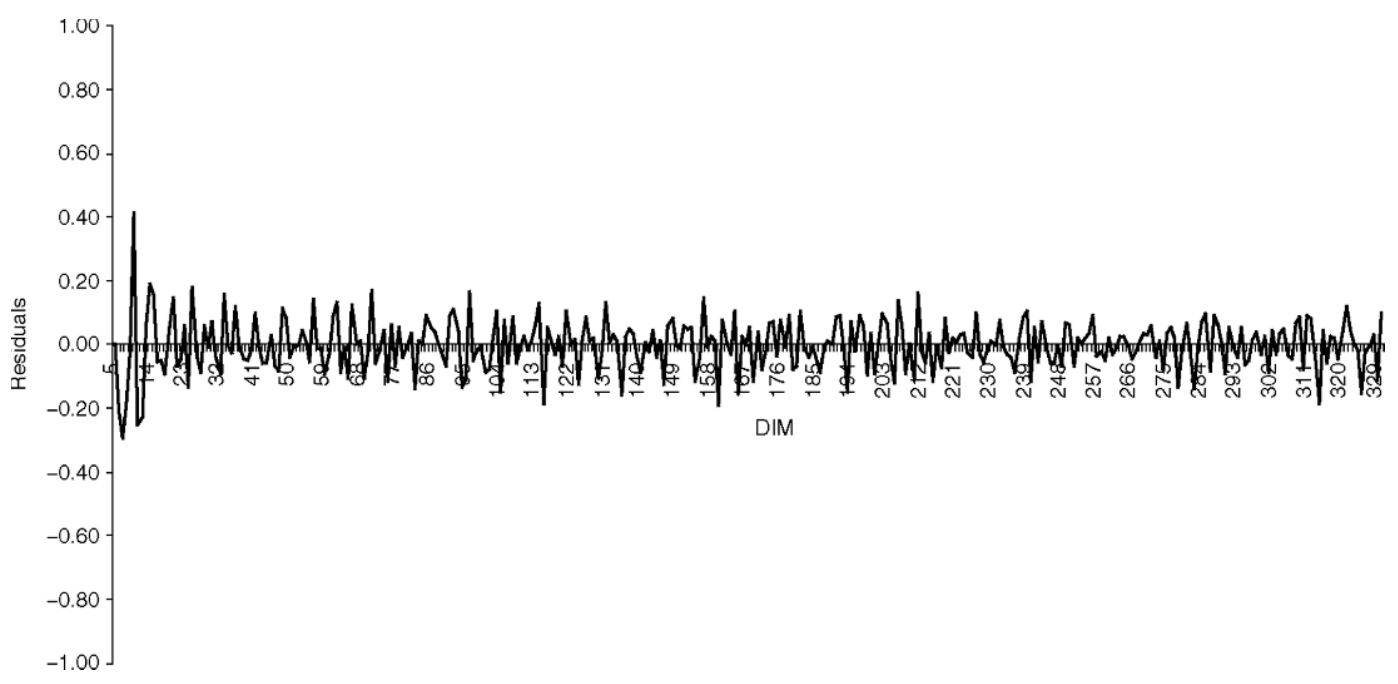

Figure 1. Mean residuals (difference between observed and estimated test-day records) by DIM for milk yield in the first lactation.

Zavadilová et al., 2005; Muir et al., 2007). The PE variance was consistently higher than $\mathrm{AG}, \mathrm{HY}$, and $\mathrm{R}$ variances for all traits in the 3 lactations. Estimated variances increased from the first to the second parity for all traits. However, the differences between all variances in the second and third lactation were small. In general, similar results were found with data from Spanish Holsteins and a repeatability model (Rekaya et al., 1999).

Misztal et al. (2000) reported that the level and pattern of daily milk yield variances obtained by RR models were heterogeneous. In the present study, the pattern of variance components across the lactation for milk yield is shown in Figure 2. The same patterns were also observed for fat and protein yields. The genetic and PE variances were generally large at the beginning, small in the middle, and moderate at the end of the lactations. The PE variance estimates were consistently larger than AG estimates throughout the lactation. In general, the trends in the $\mathrm{AG}$ and $\mathrm{PE}$ variance estimates throughout lactation obtained in this study are comparable to trends found by Olori et al. (1999), Druet et al.
(2005), Strabel et al. (2005), and Zavadilová et al. (2005). Those authors reported larger estimates of AG and $\mathrm{PE}$ variances at the beginning and end than in the middle of the lactation. However, Pool et al. (2000) and Druet et al. (2003) found opposite trends for AG variance estimates. In those studies, RR models were also applied and Legendre polynomials were used to describe random curves. However, in their analyses, the residual variance was not assumed to be constant during lactation, as in our study. Pool et al. (2000) reported that the shape of variance curves across lactation could be modeled with sufficient accuracy by using a thirdorder polynomial for the genetic part, but a fourth-order Legendre polynomial was needed for the PE. LópezRomero and Carabaño (2003) also reported that smaller order of polynomials for AG than for PE could be more suitable. Complexity of environmental effects was increased in our study by including the common HY effect.

The HY variances were the smallest compared with the other sources of variance. The HY variances were greatest at the beginning and the end of the lactation and negligible in midlactation. For all traits studied,

Table 2. Posterior means of additive genetic (AG), permanent environmental (PE), herd-year of calving (HY), and residual (R) variances (posterior SD in parentheses) of the first random regression coefficient (intercept) for milk, fat, and protein yields

\begin{tabular}{|c|c|c|c|c|c|c|c|c|c|c|c|c|}
\hline \multirow[b]{2}{*}{ Trait } & \multicolumn{4}{|c|}{ First lactation } & \multicolumn{4}{|c|}{ Second lactation } & \multicolumn{4}{|c|}{ Third lactation } \\
\hline & $\mathrm{AG}$ & $\mathrm{PE}$ & $\mathrm{HY}$ & $\mathrm{R}$ & $\mathrm{AG}$ & $\mathrm{PE}$ & $\mathrm{HY}$ & $\mathrm{R}$ & $\mathrm{AG}$ & $\mathrm{PE}$ & HY & $\mathrm{R}$ \\
\hline Milk & 1.91 & 8.46 & 0.48 & 2.98 & 2.71 & 11.94 & 0.72 & 3.58 & 2.83 & 12.69 & 0.71 & 3.84 \\
\hline Fat $(\times 1,000)$ & $\begin{array}{c}1.34 \\
(0.16)\end{array}$ & $\begin{array}{c}8.47 \\
(0.16)\end{array}$ & $\begin{array}{c}0.49 \\
(0.09)\end{array}$ & $\begin{array}{c}16.75 \\
(0.07)\end{array}$ & $\begin{array}{c}2.06 \\
(0.14)\end{array}$ & $\begin{array}{l}13.13 \\
(0.26)\end{array}$ & $\begin{array}{c}0.81 \\
(0.17)\end{array}$ & $\begin{array}{l}22.5 \\
(0.12)\end{array}$ & $\begin{array}{c}2.28 \\
(0.45)\end{array}$ & $\begin{array}{l}13.70 \\
(0.53)\end{array}$ & $\begin{array}{c}1.01 \\
(0.25)\end{array}$ & $\begin{array}{c}24.51 \\
(0.18)\end{array}$ \\
\hline Protein $(\times 1,000)$ & $\begin{array}{c}1.53 \\
(0.15)\end{array}$ & $\begin{array}{c}7.83 \\
(0.14)\end{array}$ & $\begin{array}{c}0.45 \\
(0.08)\end{array}$ & $\begin{array}{c}4.76 \\
(0.02)\end{array}$ & $\begin{array}{c}2.07 \\
(0.17)\end{array}$ & $\begin{array}{c}11.32 \\
(0.22)\end{array}$ & $\begin{array}{c}0.60 \\
(0.13)\end{array}$ & $\begin{array}{c}6.31 \\
(0.03)\end{array}$ & $\begin{array}{c}2.30 \\
(0.33)\end{array}$ & $\begin{array}{c}11.89 \\
(0.35)\end{array}$ & $\begin{array}{c}0.73 \\
(0.20)\end{array}$ & $\begin{array}{r}6.55 \\
(0.04)\end{array}$ \\
\hline
\end{tabular}




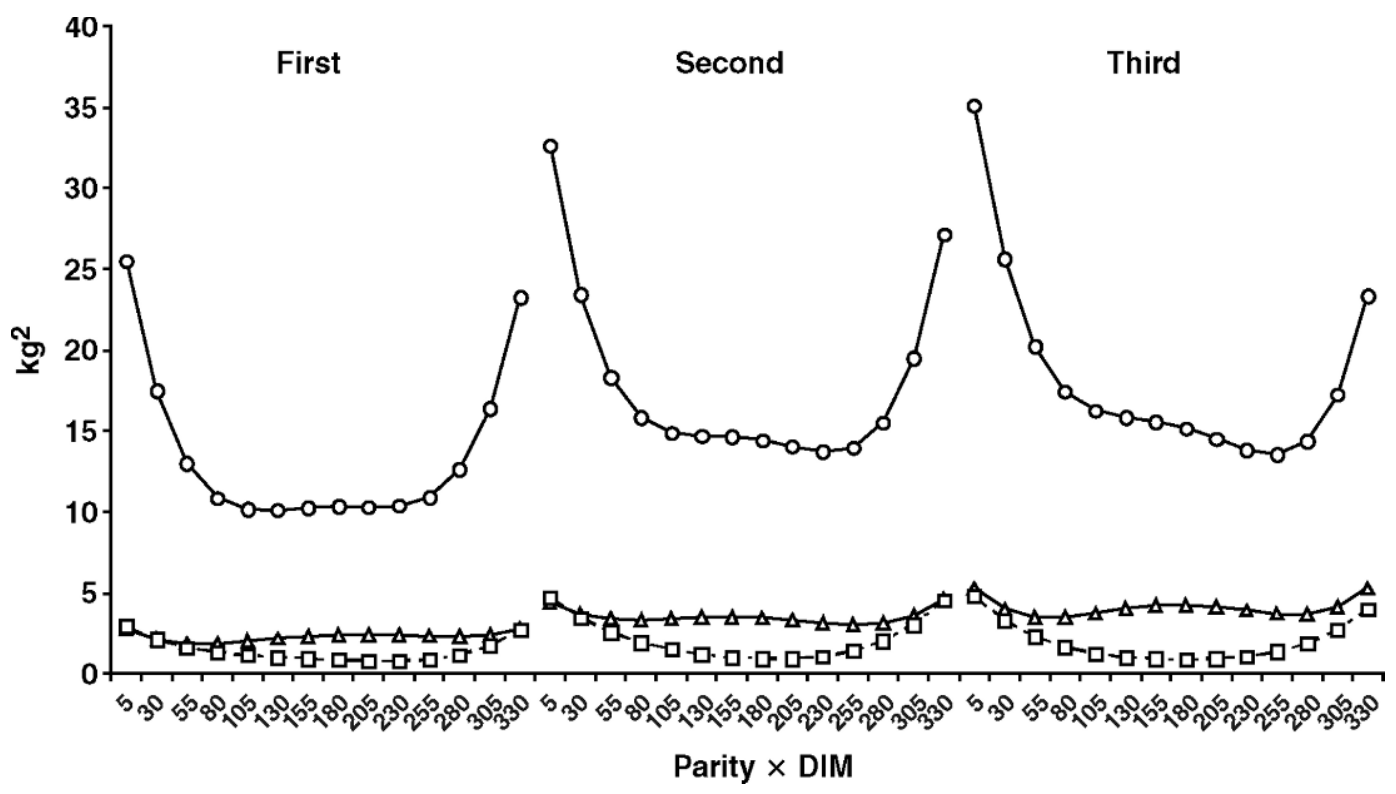

Figure 2. Additive genetic (triangles), permanent environmental (circles), and herd-year of calving common environmental variances (squares) of milk yield estimated for the first 3 lactations of Tunisian Holsteins.

the HY curve variances were typically U-shaped. The same pattern was also reported by Gengler and Wiggans (2001) and de Roos et al. (2004) and is in line with the hypothesis that the HY effect catches variance at the beginning and end of the lactations due to specific environmental influences in the different herds, such as calving preparation and dry cow management.

\section{Heritability Estimates}

Estimates of heritabilities of 305-d yield in the first 3 lactations are shown in Table 3. Estimates of 305-d heritabilities pooled over 3 lactations and computed from estimated (co)variances were greater than lactation-based estimates and were $0.25,0.17$, and 0.21 for milk, fat, and protein yield, respectively. The largest 305-d yield heritabilities were obtained for milk yield,

Table 3. Posterior means (posterior SD in parentheses) of 305-d yield heritabilities for milk, fat, and protein in the Tunisian Holsteins

\begin{tabular}{lcccc}
\hline Trait & $\begin{array}{c}\text { First } \\
\text { lactation }\end{array}$ & $\begin{array}{c}\text { Second } \\
\text { lactation }\end{array}$ & $\begin{array}{c}\text { Third } \\
\text { lactation }\end{array}$ & $\begin{array}{c}\text { Pooled } \\
\text { 305-d yield }\end{array}$ \\
\hline Milk & 0.17 & 0.18 & 0.18 & 0.25 \\
& $(0.02)$ & $(0.01)$ & $(0.02)$ & $\begin{array}{c}0.02) \\
\text { Fat }\end{array}$ \\
Protein & 0.13 & 0.12 & 0.13 & 0.17 \\
& $(0.02)$ & $(0.01)$ & $(0.03)$ & $(0.02)$ \\
& 0.15 & 0.15 & 0.15 & 0.21 \\
& $(0.02)$ & $(0.01)$ & $(0.02)$ & $(0.02)$ \\
\hline
\end{tabular}

${ }^{1}$ Pooled 305-d yield was defined as the heritability of the average of every trait over 3 lactations, and values were obtained from the summed variances and covariances for the 3 lactation 305-d yields. and the smallest heritabilities were found for fat yield. This finding was also reported by Tijani et al. (1999), Lidauer et al. (2003), Strabel and Jamrozik (2006), and Muir et al. (2007). Reents et al. (1995) and Jakobsen et al. (2002), however, obtained the smallest heritabilities for protein yield in the first lactation.

Heritabilities for 305-d milk yield in the first 3 lactations $(0.17,0.18$, and 0.18$)$ were similar to the results obtained with a 305-d repeatability model (Ben Gara et al., 2006) on the same population used for this study. They reported a mean average estimate of 0.17 (range: 0.13 to 0.21 ). The results were also comparable with $0.18,0.16$, and 0.17 obtained by Strabel and Jamrozik (2006) on Polish black and white cattle using largescale RR models. However, heritabilities of yield traits for the Tunisian Holsteins were smaller than those reported in large Holstein populations (Pool et al., 2000; Jakobsen et al., 2002; de Roos et al., 2004; Druet et al., 2005; Muir et al., 2007). De Roos et al. (2004) reported large heritability estimates for milk in the first 3 lactations $(0.51,0.49$, and 0.47$)$ using a RR model with nearly the same fixed and random effects as applied in this study. In general, the level and pattern of milk yield heritability obtained with $\mathrm{RR}$ models is sensitive to the model applied. Misztal et al. (2000) and other recent studies have confirmed this fact. Nevertheless, large estimates of AG variances and heritabilities are associated with high milk production levels (de Roos et al., 2004; Gengler et al., 2005; Druet et al., 2005; Muir et al., 2007). Low AG and heritability estimates have been 


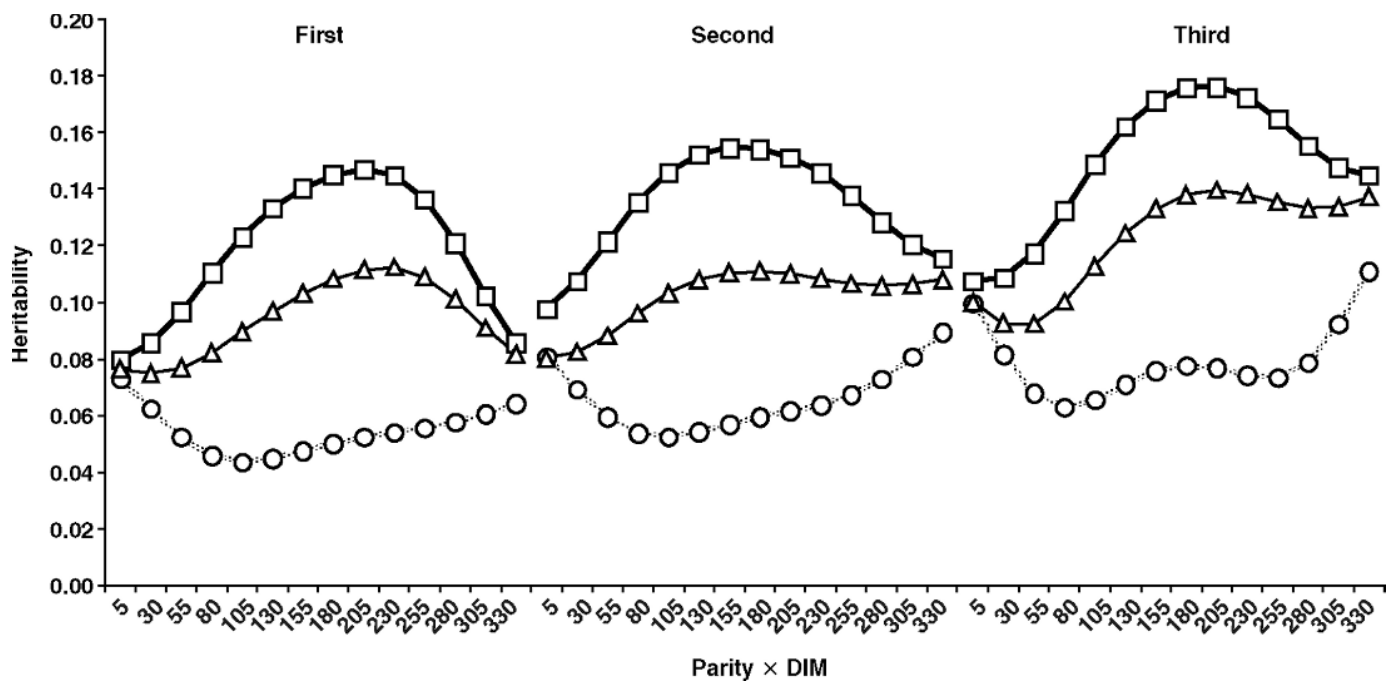

Figure 3. Heritability estimates of test-day milk (squares), protein (triangles), and fat (circles) yields.

reported for populations with low to medium production levels (e.g., Carabaño et al., 1989; Strabel and Misztal, 1999; Gengler et al., 2005; Ben Gara et al., 2006; Strabel and Jamrozik, 2006). In Tunisia, state and cooperative herds, most of which have now been dissolved, accounted for almost two-thirds of cows enrolled in the recording system up to 1998 . The cooperative and state herd production levels were 5,456 and $6,057 \mathrm{~kg}$ of milk per cow in $305 \mathrm{~d}$, respectively, over the 10 -yr period from 1990 to 1999 (Rekik et al., 2003). These lactation means are greater than those reported for Spanish Holsteins $(4,982 \mathrm{~kg}$ of milk in $305 \mathrm{~d}$ ) in the $1980 \mathrm{~s}$ (Carabaño et al., 1989). However, they were 1,700 to $2,250 \mathrm{~kg}$ less than those recorded in the 1980s on US Holsteins (Carabaño et al., 1989). Heritability estimates for milk and fat yields in the Spanish population ranged from 0.12 to 0.16 and from 0.09 to 0.14 by within- and between-country analyses with the US data, respectively. Respective estimates obtained in the same study on the US data ranged from 0.27 to 0.37 and from 0.24 to 0.33 for milk and fat yields. In fact, Veerkamp and Goddard (1998) found small heritability estimates of milk, fat, and protein yield $(0.13,0.12$, and 0.12 , respectively) for cows averaging less than $20 \mathrm{~kg}$ of daily milk yield. Our results are, therefore, in line with expectations according to these studies.

Heritabilities of TD milk yields were also determined for selected DIM (Figure 3). The trends for milk and protein TD yield heritabilities showed similar patterns. No undesired extreme estimates at the peripheries of the lactation were found for these 2 traits in the 3 lactations studied. Heritabilities were larger in the middle part of lactation than at the beginning or the end. On the other hand, heritability of TD fat yield was high in the beginning of lactation, low at the peak, and rose toward the end. In general, a heritability curve characterized by higher values in midlactation and lower values at the beginning and end of lactation is more realistic, because it is similar to results from multitrait models. The 2 extremities of lactation are generally more influenced by the farmer decision. Unreasonably large estimates of heritability at the peripheries of lactation have been found in some applications of RR models in which the PE effect was constant along the whole lactation (Jamrozik and Schaeffer, 1997) or when small data sets were analyzed with single-trait models (Strabel and Misztal, 1999). Recently, herd regression curves have been included in the RR model (Gengler and Wiggans, 2001; de Roos et al., 2004). Reported heritabilities followed the expected pattern with no artifacts observed. The patterns of milk and protein yield heritability curves of our study were in accordance with their findings when compared with a RR model without random HY effect (results not shown). In that model, heritability estimates of TD milk yields were large at the lactation extremities and small in the middle of lactation. In this study, daily heritability estimates of fat were small and did not even exceed 0.06 for two-thirds of the first lactation. The feeding system in Tunisia can be an explanation of the opposite shapes of fat heritability when compared with milk and protein patterns. Most of the farms use high-concentrate rations because of moderate quantity and quality of roughages that are readily available. Feeding diets with a high proportion of concentrate and low fiber to dairy cattle can result in decreased $\mathrm{pH}$ in the rumen, leading to depression of milk fat percentage (Bargo et al., 2003). 
Table 4. Genetic (above diagonal) and permanent environmental (below diagonal) correlations (SD in parentheses) for 305-d milk, fat, and protein yields

\begin{tabular}{|c|c|c|c|c|c|c|c|c|c|}
\hline \multirow[b]{2}{*}{ Trait $\times$ lactation } & \multicolumn{3}{|c|}{ Milk } & \multicolumn{3}{|c|}{ Fat } & \multicolumn{3}{|c|}{ Protein } \\
\hline & 1 & 2 & 3 & 1 & 2 & 3 & 1 & 2 & 3 \\
\hline \multicolumn{10}{|l|}{ Milk } \\
\hline 1 & & $\begin{array}{c}0.86 \\
(0.04)\end{array}$ & $\begin{array}{c}0.71 \\
(0.05)\end{array}$ & $\begin{array}{c}0.93 \\
(0.01)\end{array}$ & $\begin{array}{c}0.66 \\
(0.04)\end{array}$ & $\begin{array}{c}0.44 \\
(0.08)\end{array}$ & $\begin{array}{c}0.99 \\
(0.01)\end{array}$ & $\begin{array}{c}0.85 \\
(0.02)\end{array}$ & $\begin{array}{c}0.64 \\
(0.06)\end{array}$ \\
\hline 2 & $\begin{array}{c}0.39 \\
(0.01)\end{array}$ & & $\begin{array}{c}0.81 \\
(0.04)\end{array}$ & $\begin{array}{c}0.76 \\
(0.04)\end{array}$ & $\begin{array}{c}0.76 \\
(0.05)\end{array}$ & $\begin{array}{c}0.58 \\
(0.07)\end{array}$ & $\begin{array}{c}0.84 \\
(0.03)\end{array}$ & $\begin{array}{c}0.99 \\
(0.01)\end{array}$ & $\begin{array}{c}0.77 \\
(0.07)\end{array}$ \\
\hline 3 & $\begin{array}{c}0.31 \\
(0.02)\end{array}$ & $\begin{array}{c}0.36 \\
(0.03)\end{array}$ & & $\begin{array}{c}0.64 \\
(0.06)\end{array}$ & $\begin{array}{c}0.67 \\
(0.08)\end{array}$ & $\begin{array}{c}0.82 \\
(0.03)\end{array}$ & $\begin{array}{c}0.69 \\
(0.05)\end{array}$ & $\begin{array}{c}0.81 \\
(0.05)\end{array}$ & $\begin{array}{c}0.98 \\
(0.01)\end{array}$ \\
\hline \multicolumn{10}{|l|}{ Fat } \\
\hline 1 & $\begin{array}{c}0.98 \\
(0.01)\end{array}$ & $\begin{array}{c}0.35 \\
(0.01)\end{array}$ & $\begin{array}{c}0.28 \\
(0.02)\end{array}$ & & $\begin{array}{c}0.64 \\
(0.04)\end{array}$ & $\begin{array}{c}0.50 \\
(0.09)\end{array}$ & $\begin{array}{c}0.96 \\
(0.01)\end{array}$ & $\begin{array}{l}0.7 \\
(0.04)\end{array}$ & $\begin{array}{c}0.60 \\
(0.07)\end{array}$ \\
\hline 2 & $\begin{array}{c}0.35 \\
(0.01)\end{array}$ & $\begin{array}{c}0.98 \\
(0.01)\end{array}$ & $\begin{array}{c}0.33 \\
(0.02)\end{array}$ & $\begin{array}{c}0.34 \\
(0.01)\end{array}$ & & $\begin{array}{c}0.60 \\
(0.11)\end{array}$ & $\begin{array}{c}0.66 \\
(0.04)\end{array}$ & $\begin{array}{c}0.79 \\
(0.06)\end{array}$ & $\begin{array}{c}0.66 \\
(0.09)\end{array}$ \\
\hline 3 & $\begin{array}{c}0.27 \\
(0.02)\end{array}$ & $\begin{array}{c}0.33 \\
(0.02)\end{array}$ & $\begin{array}{c}0.98 \\
(0.01)\end{array}$ & $\begin{array}{c}0.26 \\
(0.02)\end{array}$ & $\begin{array}{c}0.32 \\
(0.02)\end{array}$ & & $\begin{array}{c}0.45 \\
(0.08)\end{array}$ & $\begin{array}{c}0.62 \\
(0.07)\end{array}$ & $\begin{array}{c}0.90 \\
(0.02)\end{array}$ \\
\hline \multicolumn{10}{|l|}{ Protein } \\
\hline 1 & $\begin{array}{c}0.99 \\
(0.01)\end{array}$ & $\begin{array}{c}0.38 \\
(0.01)\end{array}$ & $\begin{array}{c}0.30 \\
(0.02)\end{array}$ & $\begin{array}{c}0.98 \\
(0.01)\end{array}$ & $\begin{array}{c}0.35 \\
(0.01)\end{array}$ & $\begin{array}{c}0.27 \\
(0.02)\end{array}$ & & $\begin{array}{c}0.84 \\
(0.02)\end{array}$ & $\begin{array}{c}0.63 \\
(0.06)\end{array}$ \\
\hline 2 & $\begin{array}{c}0.38 \\
(0.01)\end{array}$ & $\begin{array}{c}0.99 \\
(0.01)\end{array}$ & $\begin{array}{c}0.36 \\
(0.02)\end{array}$ & $\begin{array}{c}0.35 \\
(0.01)\end{array}$ & $\begin{array}{c}0.99 \\
(0.01)\end{array}$ & $\begin{array}{c}0.33 \\
(0.02)\end{array}$ & $\begin{array}{c}0.37 \\
(0.01)\end{array}$ & & $\begin{array}{c}0.78 \\
(0.05)\end{array}$ \\
\hline 3 & $\begin{array}{c}0.30 \\
(0.02)\end{array}$ & $\begin{array}{c}0.36 \\
(0.01)\end{array}$ & $\begin{array}{c}0.99 \\
(0.01)\end{array}$ & $\begin{array}{c}0.27 \\
(0.02)\end{array}$ & $\begin{array}{c}0.34 \\
(0.02)\end{array}$ & $\begin{array}{c}0.99 \\
(0.01)\end{array}$ & $\begin{array}{c}0.29 \\
(0.02)\end{array}$ & $\begin{array}{c}0.36 \\
(0.02)\end{array}$ & \\
\hline
\end{tabular}

\section{Genetic and PE Correlations}

Table 4 shows genetic and PE correlations of 305-d yields. Genetic correlations obtained between the yield traits in first and second lactation (0.64 to 0.86 ) were the largest among all genetic correlation estimates. Genetic correlations ranged from 0.60 to 0.81 between the second and third lactation and from 0.50 to 0.71 between the first and third lactation. Zavadilová et al. (2005) found also that the largest genetic correlations occur between yields in adjacent lactations resulting from a multitrait RR model.

Genetic correlations (305-d yield) among production traits within lactations were high. They ranged from 0.76 to 0.93 between milk and fat yields, from 0.98 to 0.99 between milk and protein yields, and from 0.79 to 0.96 between fat and protein yields. These estimates were larger than those obtained by Muir et al. (2007) using a multiple-trait-multiple-lactation RR TD model in Italian Holsteins. Larger genetic correlation between milk and protein yield than between milk and fat yield was reported also by Jamrozik et al. (1998), Tijani et al. (1999), and Jakobsen et al. (2002). The PE correlations (305-d yields) between yield traits within lactations were also high (from 0.97 to 0.99 ). The largest genetic and PE correlations were found among first-lactation yields.

Genetic correlations between milk yields at the same DIM in the first 3 lactations are given in Figure 4. For all traits, the largest genetic correlations occurred between the first and second lactation, and the lowest were observed between the first and third lactation. The shapes of correlations across DIM showed a similar pattern for all traits and lactations with the lowest estimates at the peripheries of lactation. For milk and protein, the correlations between the same DIM in the consecutive lactations were below 0.7 at the beginning of the lactation, between 0.7 and 0.9 in the middle part, and again below 0.7 at the end of lactation. However, for fat yields, the correlations were clearly lower, not exceeding 0.72 . They were smaller than 0.5 across the whole trajectory of lactation when estimated between the same DIM of the first and third lactation. Similar shapes of correlation at the same DIM among various lactations were also reported by Strabel and Jamrozik (2006). However, the highest correlations were obtained between the second and third lactation in their analysis.

\section{General Considerations}

This study of Tunisian data found several important results. First, results suggested similar heritability values in the second and third lactation. Also, their AG variances were more similar when compared with the first parity. However, the highest genetic correlation was observed between the first and second lactation. We might speculate that these results indicate that animals in later lactations express their genetic potential differently. Furthermore, Holstein cows in Tunisia originate from temperate regions with more favorable management and climatic conditions than found in $\mathrm{Tu}-$ 


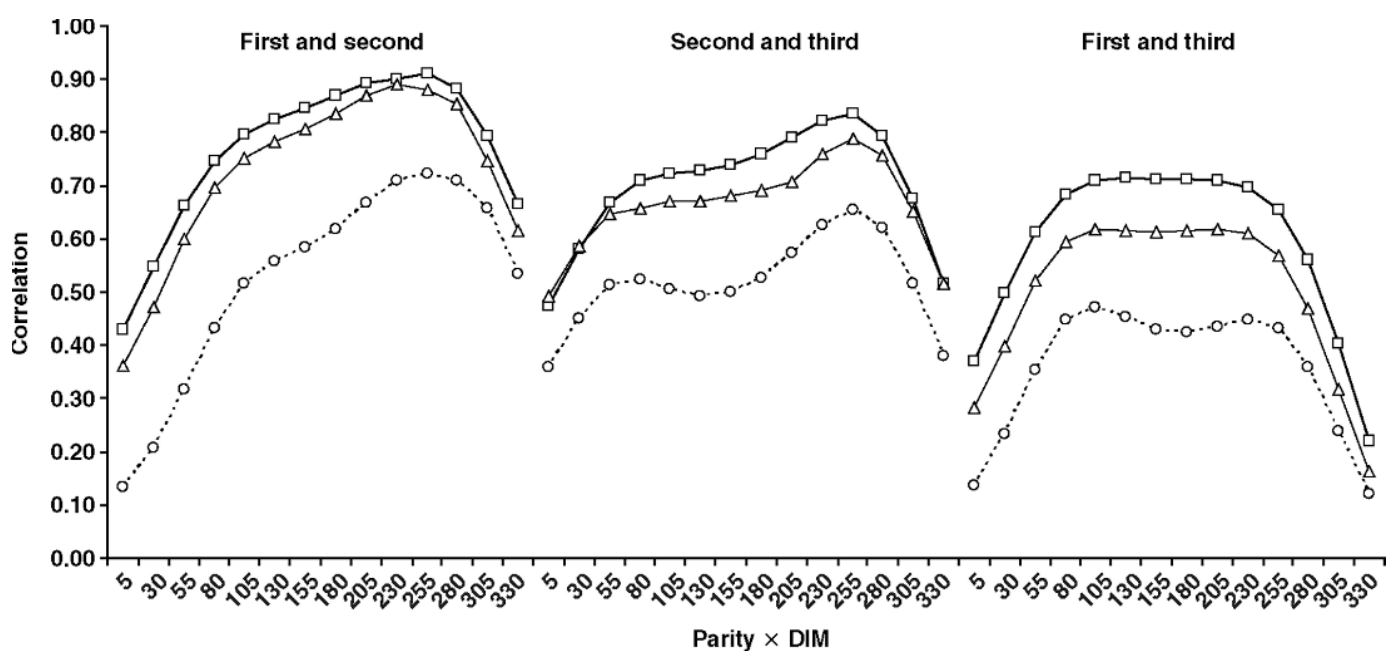

Figure 4. Genetic correlations between the 3 pairs of lactations at the same DIM for milk (squares), protein (triangles), and fat yields (circles).

nisia and may not be well adapted to the environment. This factor may be especially critical in later lactations (i.e., third lactation) when increased production adds another stress factor.

Heritabilties and genetic correlations for fat yields obtained in our study were low compared with most studies using RR models. The most likely explanation is that the high temperature and also the lack of quality forage during parts of the year can lead to decreased productivity, as reported by several authors (Ravagnolo et al., 2000; Bouraoui et al., 2002; Bohmanova et al., 2007). As found by Ravagnolo et al. (2000), fat production seems to decline more strongly than milk or protein yield as a response to heat stress. Ravagnolo et al. (2000) reported this behavior for fat compared with protein when the temperature-humidity index exceeds 72 (around $24^{\circ} \mathrm{C}$ ). The decline for fat was observed over the whole range of temperatures, whereas for milk and protein, the yields appeared relatively constant until about $24^{\circ} \mathrm{C}$ and then declined. If the latter value of temperature is considered to cause heat stress, cows in Tunisia are highly affected for almost two-thirds of the year. In addition, the process of the sampling and analysis techniques under harsh climatic situations in Tunisia puts more challenges on the cooling chain from the samples collected to their analysis. One might speculate that this could seriously affect data quality. For routine genetic evaluation, it will be important to develop integrated data quality checks similar to those used by Mayeres et al. (2003) to detect potentially affected fat content.

\section{CONCLUSIONS}

Genetic parameters of milk and protein yields obtained in this study were moderate compared with ma- jor reports on Holstein populations but were low for fat yield. However, parameter estimates were in the same range of previous results obtained in other studies of data from management systems with low to medium production levels. Low heritability estimates are caused by reduced $A G$ and increased $P E$ and $R$ variances. Genetic correlations among production traits within lactations were in general high and ranged from 0.76 to 0.99 . On the other hand, the largest correlation coefficient estimates were observed between the first and second lactation yields among all 3 lactations, whereas the smallest coefficients were found between the first and third lactations. Selection for increased later lactation yields based on EBV averaged over lactations might therefore be problematic.

Estimates of variance components found in this study may be used for the implementation of a BLUP evaluation for the Tunisian cow population, although the differences in the results for fat yields relative to milk and protein should be further investigated. Data quality management might be still an important issue for this trait. In addition, research on issues not addressed in this study, such as heterogeneity of variances, will eventually be required for implementation of an internationally accepted genetic evaluation system.

\section{ACKNOWLEDGMENTS}

The first author acknowledges the support of the Luxembourg Ministry of Culture, High Education and Research through a grant scholarship (BFR0461). Nicolas Gengler acknowledges the support of the National Fund for Scientific Research (Brussels, Belgium). The National Fund for Scientific Research supported this research by grants F.4552.05 and 2.4507.02 F (2). The 
first author also thanks the Tunisian Livestock and Pasture Office for providing data.

\section{REFERENCES}

Bargo, F., L. D. Muller, E. S. Kolver, and J. E. Delahoy. 2003. Invited review: Production and digestion of supplemented dairy cows on pasture. J. Dairy Sci. 86:1-42.

Ben Gara, A., B. Rekik, and M. Bouallègue. 2006. Genetic parameters and evaluation of the Tunisian dairy cattle population for milk yield by Bayesian and BLUP analyses. Livest. Prod. Sci. 100:142-149.

Bohmanova, J., I. Misztal, and J. B. Cole. 2007. Temperature-humidity indices as indicators of milk production losses due to heat stress. J. Dairy Sci. 90:1947-1956.

Bouraoui, R., M. Lahmar, A. Majdoub, M. Djemali, and R. Beleyea. 2002. The relationship of temperature-humidity index with milk production of dairy cows in a Mediterranean climate. Anim. Res. $51: 479-491$.

Brotherstone, S., I. M. S. White, and K. Meyer. 2000. Genetic modeling of daily milk yield using orthogonal polynomials and parametric curves. Anim. Sci. 70:407-415.

Carabaño, M. J., L. D. Van Vleck, G. R. Wiggans, and R. Alenda. 1989. Estimation of genetic parameters for milk and fat yields of dairy cattle in Spain and the United States. J. Dairy Sci. 72:3013-3022.

de Roos, A. P. W., A. G. F. Harbers, and G. de Jong. 2004. Random herd curves in a test-day model for milk, fat, and protein production of dairy cattle in the Netherlands. J. Dairy Sci. 87:2693-2701.

Druet, T., F. Jaffrézic, D. Boichard, and V. Ducrocq. 2003. Modeling lactation curves and estimation of genetic parameters for first lactation test-day records of French Holstein cows. J. Dairy Sci. 86:2480-2490.

Druet, T., F. Jaffrézic, and V. Ducrocq. 2005. Estimation of genetic parameters for test-day records of dairy traits in the first three lactations. Genet. Sel. Evol. 37:257-271.

Gengler, N., A. Tijani, G. R. Wiggans, and I. Misztal. 1999. Estimation of (co)variances function coefficient for test-day yield with expectation-maximization restricted maximum likelihood algorithm. J. Dairy Sci. 82:225.

Gengler, N., and G. R. Wiggans. 2001. Variance of effects of lactation stage within herd by herd yield. J. Dairy Sci. 84(Suppl. 1):216. (Abstr.)

Gengler, N., G. R. Wiggans, and A. Gillon. 2005. Adjustment for heterogeneous covariance due to herd milk yield by transformation of test-day random regressions. J. Dairy Sci. 88:2981-2990.

Hammami, H., C. Croquet, J. Stoll, B. Rekik, and N. Gengler. 2007. Genetic diversity and joint-pedigree analysis of two importing Holstein populations. J. Dairy Sci. 90:3530-3541.

Jakobsen, J. H., P. Madsen, J. Jensen, J. Pedersen, L. G. Christensen, and D. A. Sorensen. 2002. Genetic parameters for milk production and persistency for Danish Holsteins estimated in random regression models using REML. J. Dairy Sci. 85:1607-1616.

Jamrozik, J., and L. R. Schaeffer. 1997. Estimates of genetic parameters for a test-day model with random regressions for yield traits of first lactation Holsteins. J. Dairy Sci. 80:762-770.

Jamrozik, J., L. R. Schaeffer, and F. Grignola. 1998. Genetic parameters for production traits and somatic cell score of Canadian Holsteins with multiple trait random regression model. Proc. 6th World Congr. Genet. Appl. Livest. Prod., Armidale, Australia. 23:303-306.
Lidauer, M., E. A. Mäntysaari, and I. Strandén. 2003. Comparison of test-day models for genetic evaluation of production traits in dairy cattle. Livest. Prod. Sci. 79:73-86.

López-Romero, P., and M. J. Carabaño. 2003. Comparing alternative random regression models to analyse first lactation daily milk yield data in Holstein-Friesian cattle. Livest. Prod. Sci. 82:81-96.

Mayeres, P., A. Gillon, and N. Gengler. 2003. Integrated detection and correction of outliers in a random regression test-day model. Interbull Bull. 31:3-7.

Mayeres, P., J. Stoll, J. Bormann, R. Reents, and N. Gengler. 2004. Prediction of daily milk, fat, and protein production by a random regression model. J. Dairy Sci. 87:1925-1933.

Misztal, I., T. Strabel, J. Jamrozik, E. A. Mäntysaari, and T. H. E. Meuwissen. 2000. Strategies for estimating the parameters needed for different test-day models. J. Dairy Sci. 83:1125-1134.

Misztal, I., S. Tsuruta, T. Strabel, B. Auvray, T. Druet, and D. H. Lee. 2002. BLUPF90 and related programs (BGF90). Proc. 7th World Congr. Genet. Appl. Livest. Prod., Montpellier, France. CD-ROM communication 28:07.

Muir, B. L., G. Kistemaker, J. Jamrozik, and F. Canavesci. 2007. Genetic parameters for a multiple-trait multiple-lactation random regression test-day model in Italian Holsteins. J. Dairy Sci. 90:1564-1574.

Olori, V. E., W. G. Hill, B. J. McGuirk, and S. Brotherstone. 1999. Estimating variance components for test-day milk records by restricted maximum likelihood with a random regression animal model. Livest. Prod. Sci. 61:53-63.

Pool, M. H., L. L. G. Janss, and T. H. E. Meuwissen. 2000. Genetic parameters of Legendre polynomials for first-parity lactation curves. J. Dairy Sci. 83:2640-2649.

Ptak, E., and L. R. Schaeffer. 1993. Use of test-day yields for genetic evaluation of dairy sires and cows. Livest. Prod. Sci. 34:23-34.

Ravagnolo, O., I. Misztal, and G. Hoogenboom. 2000. Genetic component of heat stress in dairy cattle, development of heat index function. J. Dairy Sci. 83:2120-2125.

Reents, R., J. Jamrozik, L. R. Schaeffer, and J. C. M. Dekkers. 1995. Estimation of genetic parameters for test day records of somatic cell score. J. Dairy Sci. 78:2847-2857.

Rekaya, R., M. J. Carabaño, and M. A. Toro. 1999. Use of test-day yields for the genetic evaluation of production traits in HolsteinFriesian cattle. Livest. Prod. Sci. 57:203-217.

Rekik, B., A. Ben Gara, M. Ben Hammouda, and H. Hammami. 2003. Fitting lactation curves of dairy cattle in different types of herds in Tunisia. Livest. Prod. Sci. 83:309-315.

Strabel, T., and J. Jamrozik. 2006. Genetic analysis of production traits of Polish black and white cattle using large-scale random regression test-day models. J. Dairy Sci. 89:3152-3163.

Strabel, T., and I. Misztal. 1999. Genetic parameters for first and second lactation milk yields of Polish black and white cattle with random regression test-day models. J. Dairy Sci. 82:2805-2810.

Strabel, T., J. Szyda, E. Ptak, and J. Jamrozik. 2005. Comparison of random regression test-day models for Polish black and white cattle. J. Dairy Sci. 88:3688-3699.

Tijani, A., G. R. Wiggans, C. P. Tassel, J. C. Philpot, and N. Gengler. 1999. Use of (co)variance functions to describe (co)variances for test-day yield. J. Dairy Sci. 82:226.

VanRaden, P. M. 1997. Lactation yields and accuracies computed from test-day yields and (co)variances by best prediction. J. Dairy Sci. 80:3015-3022.

Veerkamp, R. F., and M. E. Goddard. 1998. Covariance functions across herd production levels for test-day records on milk, fat, and protein yields. J. Dairy Sci. 81:1690-1701.

Zavadilová, L., J. Jamrozik, and L. R. Schaeffer. 2005. Genetic parameters for test-day model with random regressions for production traits of Czech Holstein cattle. Czech J. Anim. Sci. 50:142-154. 